\title{
Probing the role of metal ions on reversible peptide-protein interactions by NMR
}

\author{
Nicola D’Amelio, Elena Gaggelli *, Nicola Gaggelli, Francesca Mancini, Elena Molteni, \\ Daniela Valensin and Gianni Valensin \\ Department of Chemistry and the NMR Center, University of Siena, Via A.Moro, Siena 53100, Italy
}

\begin{abstract}
This work provides evidence that paramagnetic lanthanide ions constitute ideal probes suitable for investigations of metal effects upon peptide-receptor interactions with the use of NMR methods. Cerium(III) is herein used for assessing metal effects upon the interaction between angiotensin II and a fragment from the $\mathrm{AT}_{1 \mathrm{~A}}$ receptor. Angiotensin II forms a complex with cerium(III) in water while the $\mathrm{fCT}^{300-320}$ receptor fragment is poorly affected by cerium(III). However, the addition of the fragment displaces cerium(III) from the complex, thus directly demonstrating the higher affinity of angiotensin II for the receptor and probing the peptide residues involved in receptor binding.
\end{abstract}

Keywords: NMR, ${ }^{1} \mathrm{H}$, angiotensin $\mathrm{II}, \mathrm{AT}_{1 \mathrm{~A}}$ receptor, lanthanides, cerium(III)

\section{Abbreviations}

COSY, correlation spectroscopy; HPLC, high pressure liquid chromatography; MALDITOF, matrix assisted laser desorption/ionization time of flight; MRI, magnetic resonance imaging; NMR, nuclear magnetic resonance; ROESY, rotating frame Overhauser effect spectroscopy; TOCSY, total correlation

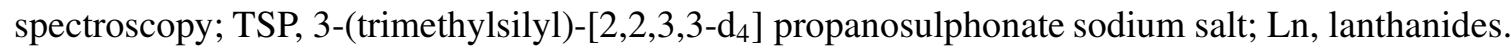

\section{Introduction}

Peptides are primary messengers for inter-cellular communication in biological systems. In contrast to DNA recognition, the information content is not encoded into the sequence, but depends on the threedimensional structure. Since most peptides are intrinsically extremely flexible, such "active" structure results from nearest-neighbor contacts with the protein receptor surface (conformational selection). Electrostatics is likely to play a major role in such a process and, as a consequence, charged metal ions are expected to actively modulate the interaction.

We herein provide evidence that paramagnetic lanthanide ions constitute ideal suitable probes for investigations of metal effects upon peptide-receptor interactions with the use of NMR methods. As a matter of fact, lanthanides have already been successfully exploited for (i) probing the metal binding site in metalloproteins [1], (ii) delineating exposed residues on protein surfaces [2,3], and (iii) enhancing contrast in MRI [4-6]. We have considered the interaction of angiotensin II (Asp-Arg-Val-Tyr-Ile-HisPro-Phe, AngII), a peptide playing a critical role in regulation of cardiovascular homeostasis [7] with

\footnotetext{
${ }^{*}$ Corresponding author. Tel.: +39 577 234243; Fax: +39 577 234254; E-mail: gaggelli@ unisi.it.
} 
a sequence taken from the C-terminus (Leu-Phe-Tyr-Gly-Phe-Leu-Gly-Lys-Lys-Phe-Lys-Lys-Tyr-PheLeu-Gln-Leu-Leu-Lys-Tyr-Ile, $\mathrm{fCT}^{300-320}$ ) of its $\mathrm{AT}_{1}$ receptor [8], with the aim of ascertaining the potential of the method in cases of reversible associations. Ang II is long known to behave as a flexible unstructured peptide in polar environments, but calcium [9] or lanthanide (III) ions [10] force the peptide to assume a folded hairpin configuration that discloses a striking similarity with one of the structures suggested for bound Ang II [11]. It follows that the metal is likely to act as agonist or antagonist for the Ang II-AT ${ }_{1}$ interaction.

We used $\mathrm{Ce}$ (III) as the lanthanide because (i) its ionic radius is very close to that of $\mathrm{Ca}$ (II) and (ii) its large magnetic susceptibility causes large shifts of proton signals [1], thus amplifying the effects of metal binding.

\section{Experimental}

Ang II was purchased from Sigma Cheamical Co. as acetate and used without further purification. $\mathrm{fCT}^{300-320}$ was assembled using a Syro peptide synthesizer (MultiSynTech, Bochum, D) on a Rink amide MBHA resin. Standard solid-phase chemistry based on the Fmoc protection group and $\mathrm{DIC} / \mathrm{HOBt}$ activation was employed. The following side-chain protecting groups were used: t-butyl for Tyr, t-butoxycarbonyl for Lys and trityl for Gln. The peptide was side-chain deprotected and cleaved from the resin by treatment with trifluoracetic acid (TFA) containing ethandithiol, water, triisobutylsilane and anisole (93/2.5/2/1.5/1). After precipitation by ethylic ether, the crude peptide was purified by reverse-phase HPLC on a Vydac C18 column $(1.0 \times 25 \mathrm{~cm})$, using a 30 min linear gradient from 30 to $100 \%$ of methanol in water (both containing $0.1 \%$ of TFA). Purity and structural integrity of the peptide were confirmed by analytical HPLC and by MALDITOF on a Biflex III spectrometer (Bruker, Breemen, D).

NMR spectra were performed at $14.1 \mathrm{~T}$ with a Bruker Avance $600 \mathrm{MHz}$ spectrometer at controlled temperatures $( \pm 0.1 \mathrm{~K})$. The peptides were dissolved in a solution of deionized water containing $\mathrm{D}_{2} \mathrm{O}$ $(10 \%)$. The $\mathrm{pH}$ was adjusted at $\mathrm{pH}=4.0$ with either $\mathrm{DCl}$ or $\mathrm{NaOD}$. The desired concentration of cerium ions was achieved by using a stock solution of cerium(III) chloride (Sigma Chemical Co.) in deionized water at $\mathrm{pH}$ 4.0. The experiments were carried out at the constant ionic strength $I=150 \mathrm{mM}$. The assignment was obtained by TOCSY, COSY, and ROESY 2D experiments. TOCSY spectra were recorded with a total spin-locking time of $75 \mathrm{~ms}$ using a MLEV-17 mixing sequence; ROESY spectra were performed with a standard pulse sequence using a ROESY spin-lock of $350 \mathrm{~ms}$ and a power of $2.3 \mathrm{kHz}$. During all 2D experiments, water suppression was achieved by excitation sculpting and presaturation methods. The spectral width of homonuclear 2D experiments was typically $6600 \mathrm{~Hz}$ in both $F_{1}$ and $F_{2}$ dimensions.

\section{Results and discussion}

All NMR spectra were recorded at $\mathrm{pH} 4.0$ and $318 \mathrm{~K}$, conditions that provided the best lineshape and are reported to maximize the occurrence of secondary structure in $\mathrm{fCT}^{300-320}$ [12]. Chemical shifts are summarized in Tables 1 and 2. Figure 1 shows the effects of adding $\mathrm{Ce}^{3+}$ on the NMR spectrum of Ang II: the most affected ${ }^{1} \mathrm{H}$ signals belong to ${ }^{8} \mathrm{Phe}$. Among the others, the $\mathrm{H}_{\beta}$ of ${ }^{1} \mathrm{Asp}$ and the $\mathrm{H}_{\varepsilon}$ of ${ }^{6} \mathrm{His}$ were also largely affected, as expected for both the Asp and terminal carboxyl groups binding the metal $[9,10]$. The most affected proton resonance (the amide proton of ${ }^{8} \mathrm{Phe}$ ) was used to evaluate the 
Table 1

${ }^{1} \mathrm{H}$ chemical shifts of Ang II $2.8 \mathrm{mM}$ in $\mathrm{H}_{2} \mathrm{O}$ (containing $10 \% \mathrm{D}_{2} \mathrm{O}$ ) at $\mathrm{pH} 4.0, T=318 \mathrm{~K}$. Chemical shifts were referenced to internal TSP

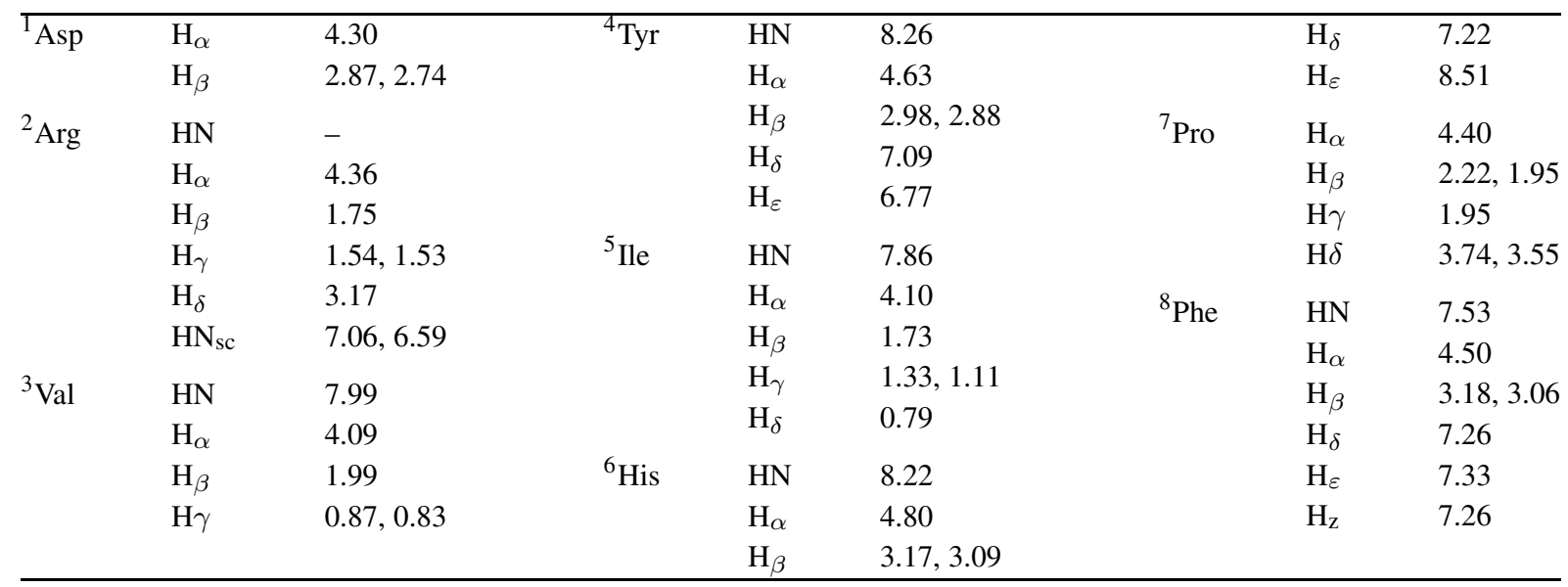

Table 2

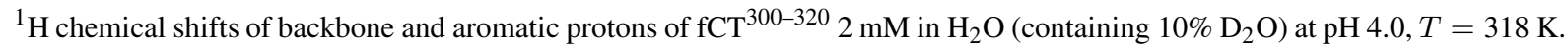
Chemical shifts were referenced to internal TSP

\begin{tabular}{|c|c|c|c|c|c|c|c|c|}
\hline \multirow[t]{2}{*}{${ }^{1}$ Leu } & $\mathrm{HN}$ & - & ${ }^{7}$ Gly & $\mathrm{HN}$ & 7.91 & & $\mathrm{H}_{\alpha}$ & 4.29 \\
\hline & $\mathrm{H}_{\alpha}$ & 3.87 & & $\mathrm{H}_{\alpha}$ & 3.99 & & $\mathrm{H}_{\delta}$ & 7.15 \\
\hline \multirow[t]{5}{*}{${ }^{2} \mathrm{Phe}$} & $\mathrm{HN}$ & & ${ }^{8}$ Lys & $\mathrm{HN}$ & 8.15 & & $\mathrm{H}_{\varepsilon}$ & 6.85 \\
\hline & $\mathrm{H}_{\alpha}$ & 4.49 & & $\mathrm{H}_{\alpha}$ & 4.16 & & $\mathrm{H}_{\mathrm{z}}$ & 7.24 \\
\hline & $\mathrm{H}_{\delta}$ & 7.19 & ${ }^{9} \mathrm{Ivs}$ & $\mathrm{HN}$ & 815 & \multirow[t]{2}{*}{${ }^{15}$ Leu } & $\mathrm{HN}$ & 8.09 \\
\hline & $\mathrm{H}_{\varepsilon}$ & 7.29 & & $\mathrm{H}_{\alpha}$ & $\begin{array}{l}0.15 \\
4.17\end{array}$ & & $\mathrm{H}_{\alpha}$ & 4.07 \\
\hline & $\mathrm{H}_{\mathrm{z}}$ & - & \multirow{5}{*}{${ }^{10} \mathrm{Phe}$} & & & \multirow[t]{2}{*}{${ }^{16} \mathrm{Gln}$} & $\mathrm{HN}$ & 7.85 \\
\hline \multirow[t]{4}{*}{${ }^{3} \mathrm{Tyr}$} & $\mathrm{HN}$ & 8.03 & & HN & $\begin{array}{l}7.97 \\
450\end{array}$ & & $\mathrm{H}_{\alpha}$ & 4.13 \\
\hline & $\mathrm{H}_{\alpha}$ & 4.43 & & $\begin{array}{l}\mathrm{I}_{\alpha} \\
\mathrm{H}_{\delta}\end{array}$ & $\begin{array}{l}4.50 \\
7.19\end{array}$ & ${ }^{17}$ Leu & $\mathrm{HN}$ & 7.89 \\
\hline & $\mathrm{H}_{\delta}$ & 7.01 & & $\mathrm{H}_{\varepsilon}$ & 7.23 & & $\mathrm{H}_{\alpha}$ & 4.12 \\
\hline & $\mathrm{H}_{\varepsilon}$ & 6.81 & & $\mathrm{H}_{\mathrm{z}}$ & - & ${ }^{18}$ Leu & $\mathrm{HN}$ & 7.86 \\
\hline \multirow[t]{2}{*}{${ }^{4}$ Gly } & HN & 7.50 & \multirow{2}{*}{${ }^{11}$ Lys } & HN & 8.01 & & $\begin{array}{l}\text { HIN } \\
\mathrm{H}_{\alpha}\end{array}$ & $\begin{array}{l}1.80 \\
4.04\end{array}$ \\
\hline & $\mathrm{H}_{\alpha}$ & 3.74 & & $\mathrm{H}_{\alpha}$ & 4.01 & ${ }^{19} \mathrm{I}_{\mathrm{H}}$ & & \\
\hline \multirow[t]{5}{*}{${ }^{5} \mathrm{Phe}$} & $\mathrm{HN}$ & 7.79 & \multirow{3}{*}{${ }^{12}$ Lys } & $\mathrm{HN}$ & 794 & \multirow{5}{*}{${ }^{20} \mathrm{Tyr}$} & $\mathrm{HN}$ & $\begin{array}{l}7.70 \\
4.08\end{array}$ \\
\hline & $\mathrm{H}_{\alpha}$ & 4.53 & & Hiv & 1.94 & & $\mathbf{H}_{\alpha}$ & 4.08 \\
\hline & $\mathrm{H}_{\delta}$ & 7.20 & & $\mathbf{H}_{\alpha}$ & 4.09 & & $\mathrm{HN}$ & 7.81 \\
\hline & $\mathrm{H}_{\varepsilon}$ & 7.28 & ${ }^{13} \mathrm{Tyr}$ & $\mathrm{HN}$ & 7.78 & & $\mathrm{H}_{\alpha}$ & 4.50 \\
\hline & $\mathrm{H}_{\mathrm{z}}$ & 7.30 & & $\mathrm{H}_{\alpha}$ & 4.43 & & $\mathrm{H}_{\delta}$ & 7.07 \\
\hline \multirow[t]{3}{*}{${ }^{6}$ Leu } & HN & 7.88 & & $\mathrm{H}_{\delta}$ & 6.99 & \multirow{3}{*}{${ }^{21}$ Ile } & $\mathrm{H}_{\varepsilon}$ & 6.84 \\
\hline & $\mathrm{H}_{\alpha}$ & 4.25 & & $\mathrm{H}_{\varepsilon}$ & 6.78 & & $\mathrm{HN}$ & 7.74 \\
\hline & & & ${ }^{14} \mathrm{Phe}$ & $\mathrm{HN}$ & 8.28 & & $\mathrm{H}_{\alpha}$ & 4.05 \\
\hline
\end{tabular}



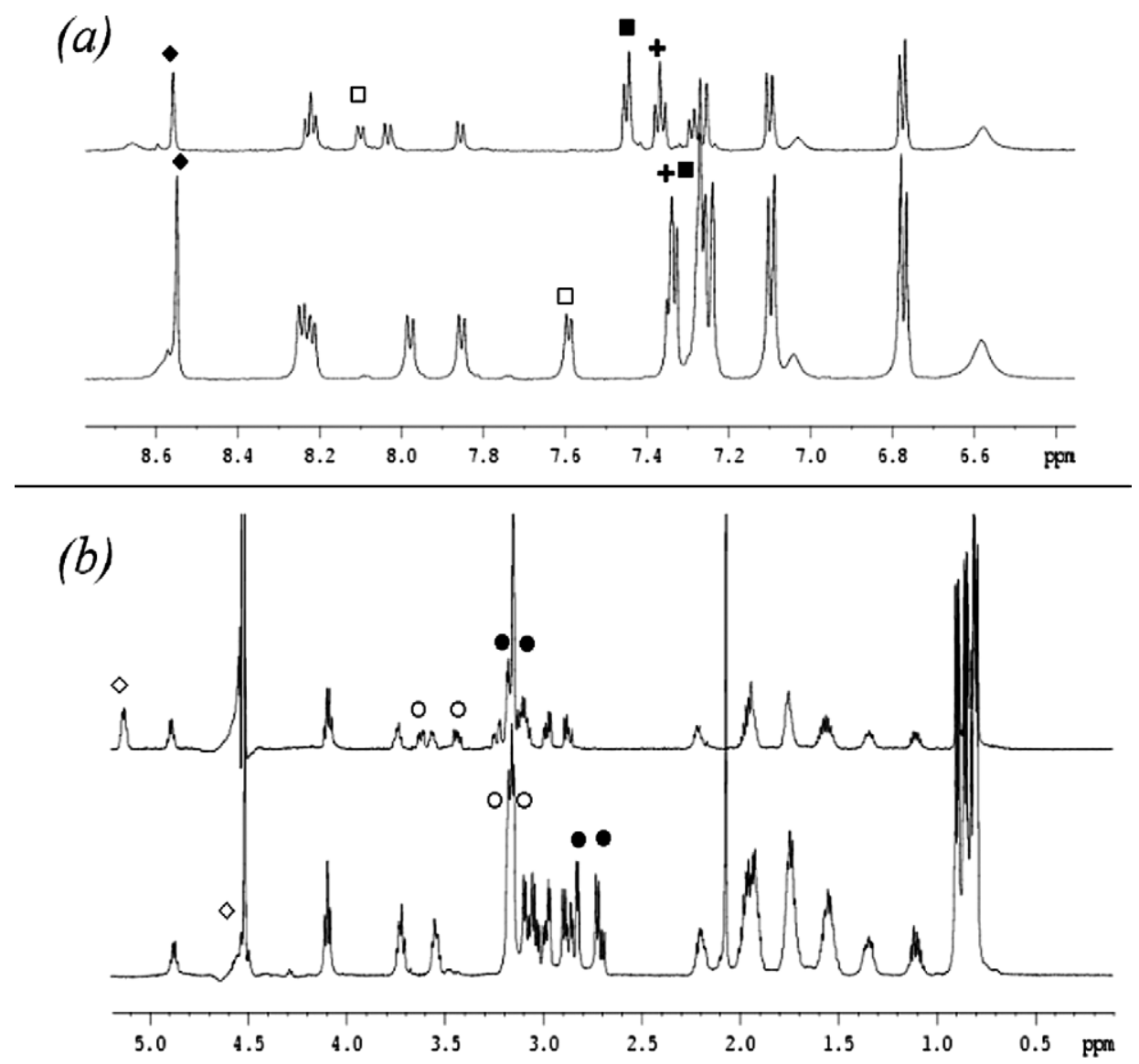

Fig. 1. Low- (a) and high-field (b) regions of superimposed ${ }^{1} \mathrm{H}-\mathrm{NMR}$ spectra of angiotensin II $5.00 \mathrm{mM}$ in $\mathrm{H}_{2} \mathrm{O} / \mathrm{D}_{2} \mathrm{O} 9 / 1$ in the absence (bottom) and in the presence (top) of $\mathrm{Ce}^{3+} 0.125 \mathrm{M}$ at $T=318 \mathrm{~K}, \mathrm{pH}=4.0 .{ }^{8}$ Phe $\mathrm{HN}$ (empty square), $\mathrm{H}_{\alpha}$ (empty rhombus), $\mathrm{H}_{\beta}$ (empty circle), $\mathrm{H}_{\delta}$ (cross) and $\mathrm{H}_{\varepsilon}$ (filled square), ${ }^{1} \mathrm{Asp} \mathrm{H}_{\beta}$ (filled circle) and ${ }^{6} \mathrm{His}_{\varepsilon}$ (filled rhombus) display shift.

dissociation constant $\left(K_{\mathrm{d}}=33.8 \pm 2 \mathrm{mM}\right)$ and the stoichiometry of the metal complex $(n=1.01 \pm 0.03)$ by using reported methods $[13,14]$.

In contrast with Ang II, the fCT fragment was poorly affected by the addition of $\mathrm{Ce}^{3+}$. Small (ca. $0.05 \mathrm{ppm}$ ) downfield shifts were observed for almost all amide protons, thus suggesting that this 21-mer does not provide any specific binding site for the lanthanide ion. These findings were not unexpected due to lacking of Asp or Glu residues that usually act as anchoring sites for calcium and Ln(III).

Upon binding to the fCT fragment, all amide protons of Ang II, especially the ${ }^{8} \mathrm{Phe} \mathrm{HN}$, were shifted downfield $(0.05-0.15 \mathrm{ppm}$ at fCT : Ang II $1: 2)$ and, at a lesser extent, the same occurred for ${ }^{6} \mathrm{His}$ and ${ }^{8} \mathrm{Phe}$ aromatic protons [15]. The shifts experienced by $\mathrm{HN}, \mathrm{H}_{\alpha}$ and aromatic protons of fCT allowed to locate the interaction site at level of the N-terminus, involving the ${ }^{1} \mathrm{Asp}$ and ${ }^{8} \mathrm{Phe}$ of Ang II and implying a well defined pairing pattern of aromatic rings [15]. For the present purposes, it is worth underlining that the shifts induced by $\mathrm{Ce}^{3+}$ were two-, three-fold larger than those determined by the addition of fCT.

It was then observed that addition of fCT $1.0 \mathrm{mM}$ to Ang II $0.25 \mathrm{mM}$ almost completely quenched the paramagnetic shifts induced by $\mathrm{Ce}^{3+} 0.50 \mathrm{mM}$ (Fig. 2). Such behavior may be in principle determined by: 


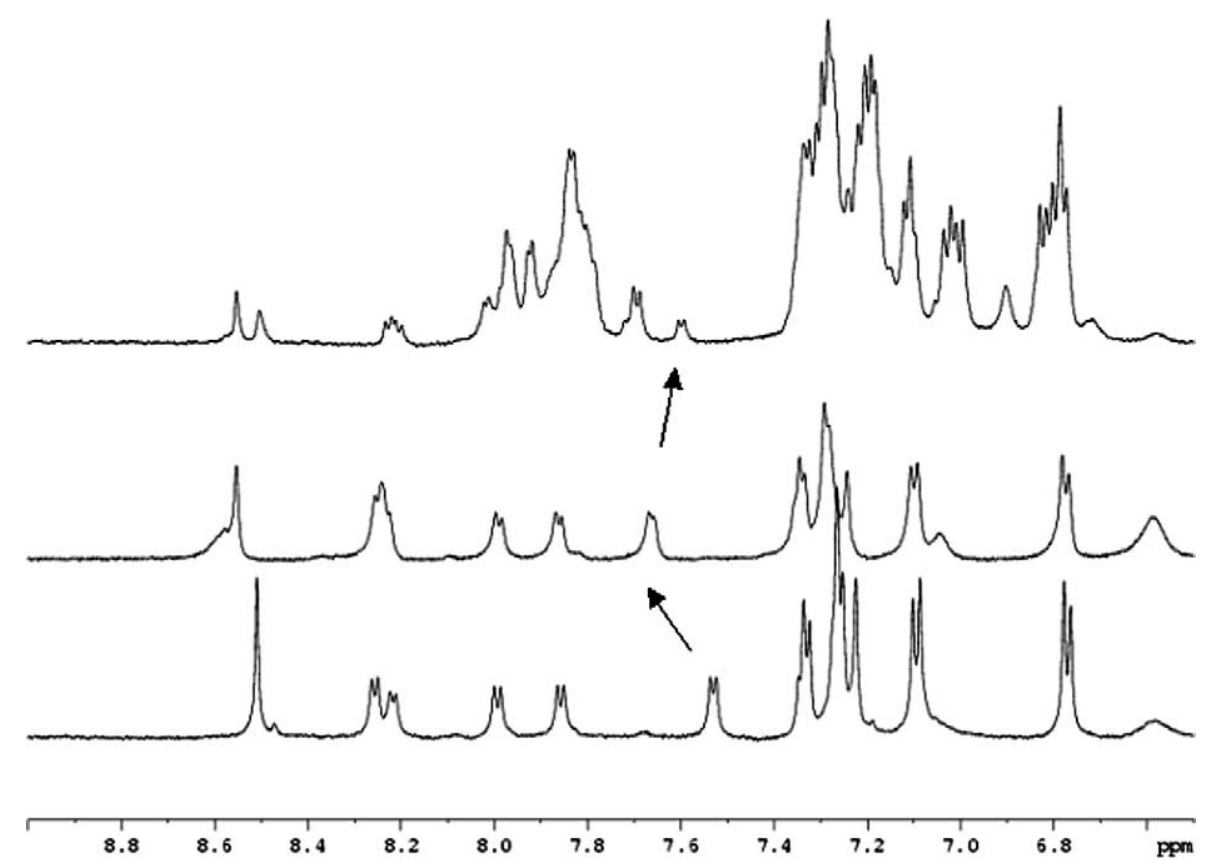

Fig. 2. Superimposed ${ }^{1} \mathrm{H}-\mathrm{NMR}$ spectra of angiotensin II $0.25 \mathrm{mM} 5$ in $\mathrm{H}_{2} \mathrm{O} / \mathrm{D}_{2} \mathrm{O} 9 / 1$ alone (bottom), in the presence of $\mathrm{Ce}^{3+}$ $0.50 \mathrm{mM}$ (center), in the presence of $\mathrm{Ce}^{3+} 0.50 \mathrm{mM}$ and of $\mathrm{fCT}^{300-320} 1.00 \mathrm{mM}$ (top) at $T=318 \mathrm{~K}, \mathrm{pH}=4.0$. The arrows show the shift induced by $\mathrm{Ce}^{3+}$ on ${ }^{8} \mathrm{Phe} \mathrm{HN}$ and the quenching effect caused by the addition of $\mathrm{fCT}^{300-320}$.

(i) formation of a new (ternary) complex, in fast exchange with the old one, with a reoriented magnetic susceptibility tensor of the lanthanide that changes the sign of observed shifts;

(ii) competition of fCT and Ang II for $\mathrm{Ce}^{3+}$ that is displaced from its original binding site;

(iii) competition of fCT and $\mathrm{Ce}^{3+}$ for Ang II: the lanthanide is displaced from its original binding sites on Ang II because the same groups are now engaged in a (more) specific interaction with the receptor peptide.

At the light of the observed poor affinity of $\mathrm{Ce}^{3+}$ for the fCT fragment, we believe hypothesis (iii) is the most reliable and the simplest in accounting for the observed phenomena. That this is the case is further supported by the observation that ${ }^{1} \mathrm{Asp}$ and ${ }^{8} \mathrm{Phe}$ of Ang II are both involved in binding either $\mathrm{Ce}^{3+}$ or fCT.

It is therefore concluded that paramagnetic lanthanide ions provide a simple NMR tool that may add some valuable information on the role metal ions, especially calcium, play in reversible peptide-receptor interactions. The value of the dissociation constant and the consequent fast exchange regime (the chemical shift induced by the metal is a linear function of the molar fraction of the bound form) assure that the complex is kinetically labile and thus well suited to investigate whether and how its formation and structure are affected by the presence of the receptor for the peptide. The observed canceling of paramagnetic effects upon addition of the $\mathrm{fCT}^{300-320}$ fragment is therefore directly probing not only that Ang II obviously has a larger affinity for the receptor than for the metal but also that the metal and the receptor compete for the same donors in the peptide.

The same approach is expected to encompass all cases where the paramagnetic ion finds a much more specific binding site in one than in the other of the interacting pair; whereas the reversibility of the peptide-receptor interaction is not probably of concern. In the considered example, since the metal 
forces Ang II to assume a conformation resembling the hairpin suggested as a possible biological active structure [11], it may be speculated that the metal ion aids in selecting an active structure of the peptide without severely affecting the interaction modes at the biological target.

\section{Acknowledgement}

We would like to acknowledge the CIRMMP (Consorzio Interuniversitario Risonanze Magnetiche di Metalloproteine Paramagnetiche) for financial support.

\section{References}

[1] I. Bertini, C. Luchinat and G. Parigi, Magnetic susceptibility in paramagnetic NMR, Progr. NMR Spectrosc. 40 (2002), 249-273, and references therein.

[2] L.R. Dick, C.F.G.C. Geraldes, A.D. Sherry, C.W. Gray and D.M. Gray, 13C NMR of methylated lysines of fd gene 5 protein: evidence for a conformational change involving lysine 24 upon binding of a negatively charged lanthanide chelate, Biochemistry 28 (1989), 7896-7904.

[3] S. Aime, N. D’Amelio, M. Fragai, Y.M. Lee, C. Luchinat, E. Terreno and G. Valensin, A paramagnetic probe to localize residues next to carboxylates on protein surfaces, J. Biol. Inorg. Chem. 7 (2002), 617-622.

[4] J.A. Peters, J. Huskens and D.J. Raber, Lanthanide induced shifts and relaxation rate enhancements, Progr. NMR Spectrosc. 28 (1996), 283-350.

[5] S. Aime, M. Botta, M. Fasano and E. Terreno, Lanthanide(III) chelates for NMR biomedical applications, Chem. Soc. Rev. 27 (1998), 19-29.

[6] P. Caravan, J.J. Ellison, T.J. McMurry and R.B. Lauffer, Gadolinium(III) chelates as MRI contrast agents: structure, dynamics, and applications, Chem. Rev. 99 (1999), 2293-2352.

[7] M. De Gasparo, K.J. Catt, T. Inagami, J.W. Wright and T.H. Unger, International union of pharmacology. XXIII. The angiotensin II receptors, Pharmacol. Rev. 52 (2000), 415-472.

[8] P.B. Timmermans, P.C. Wong, A.T. Chiu and W.F. Herblin, Nonpeptide angiotensin II receptor antagonists, Trends Pharmacol. Sci. 12 (1991), 55-62.

[9] E. Gaggelli, N. D'Amelio, N. Gaggelli, D. Valensin, A. Maccotta and G. Valensin, NMR studies of calcium complexes of biological active peptides, Recent Res. Develop. Inorganic. Chem. 2 (2000), 131-144.

[10] R.E. Lenkinski and R.L. Stephens, The nature of the $\mathrm{Ln}^{3+}$-angiotensin II complex. A $13 \mathrm{C} \mathrm{nmr}$ study of the binding of $\mathrm{Yb}^{3+}$ to angiotensin II, J. Inorg. Biochem. 18 (1983), 175-180.

[11] K.C. Garcia, P.M. Ronco, P.J. Verroust, A.T. Brunger and L.M. Amzel, Three-dimensional structure of an angiotensin II-Fab complex at 3 A: hormone recognition by an anti-idiotypic antibody, Science 257 (1992), $502-507$.

[12] L. Franzoni, G. Nicastro, T.A. Perthinez, M. Tatò, C.R. Nakaie, A.C.M. Paiva, S. Schreier and A. Spisni, Structure of the C-terminal fragment 300-320 of the rat angiotensin II AT1 $1_{\mathrm{A}}$ receptor and its relevance with respect to G-protein coupling, J. Biol. Chem. 272 (1997), 9734-9741.

[13] J. Reuben, Complex formation betwee Eu(fod)3, a lanthanide shift reagent, and organic molecules, J. Am. Chem. Soc. 95 (1973), 3534-3540.

[14] C.K. Vishwanath and K.R. Easwaran, Hydrogen-1 and carbon-13 magnetic resonance studies of nonactin-calcium complex, Biochemistry 20 (1981), 2018-2023.

[15] N. D’Amelio, E. Gaggelli, N. Gaggelli, L. Lozzi, P. Neri, D. Valensin and G. Valensin, Interaction of angiotensin II with the C-terminal 300-320 fragment of the rat angiotensin II receptor AT1a monitored by NMR, Biopolymers (2003), in press. 


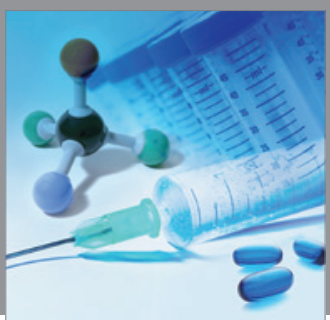

International Journal of

Medicinal Chemistry

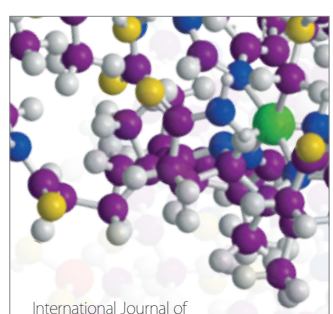

Carbohydrate Chemistry

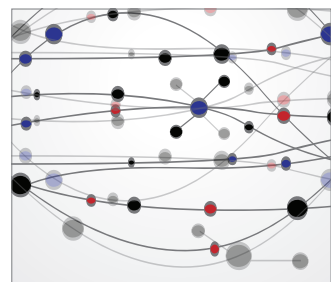

The Scientific World Journal
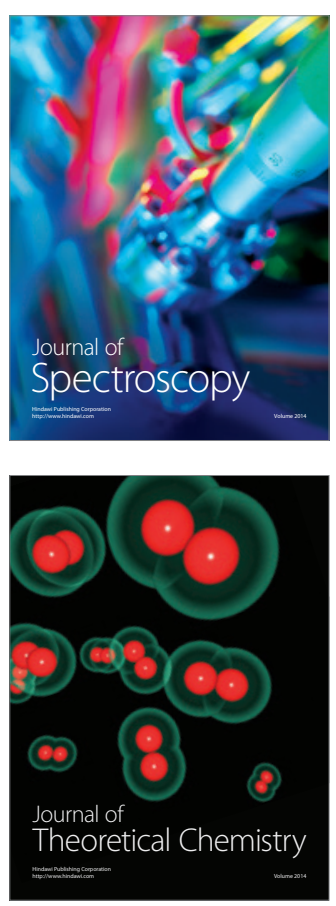
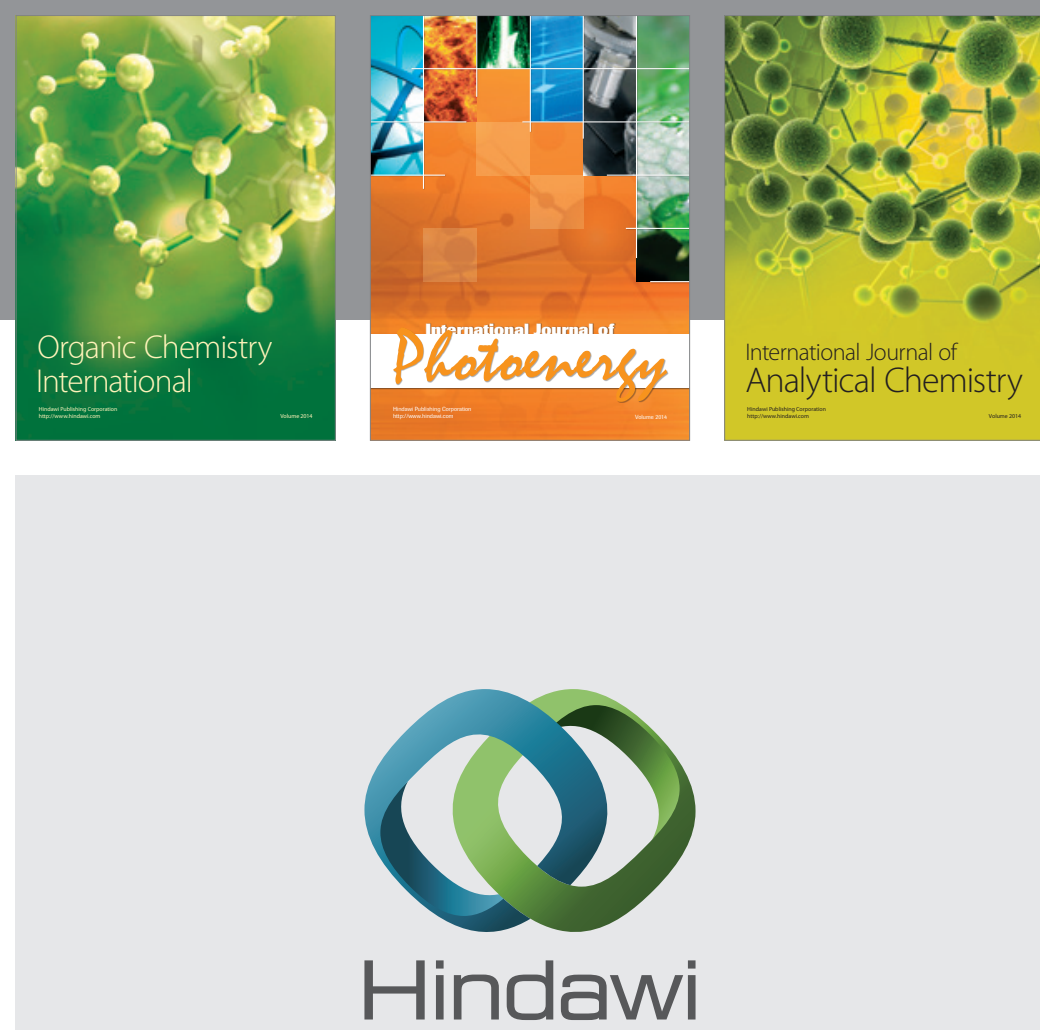

Submit your manuscripts at

http://www.hindawi.com
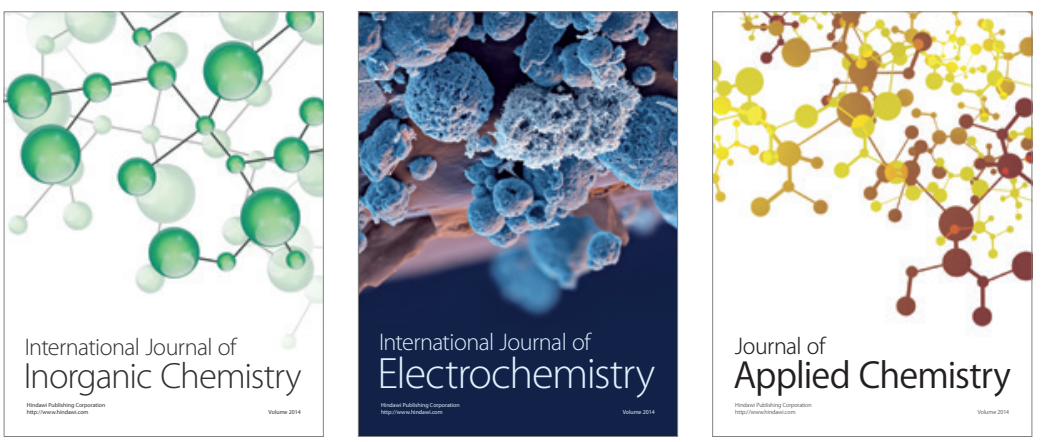

Journal of

Applied Chemistry
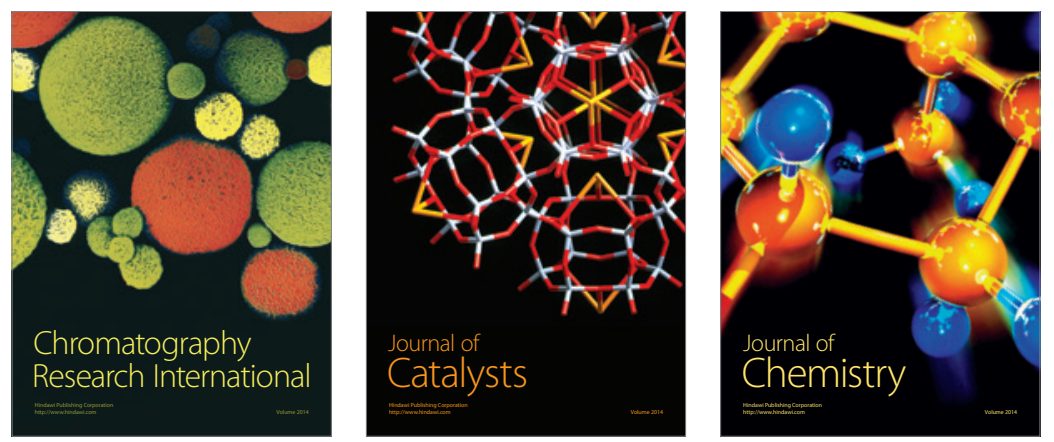
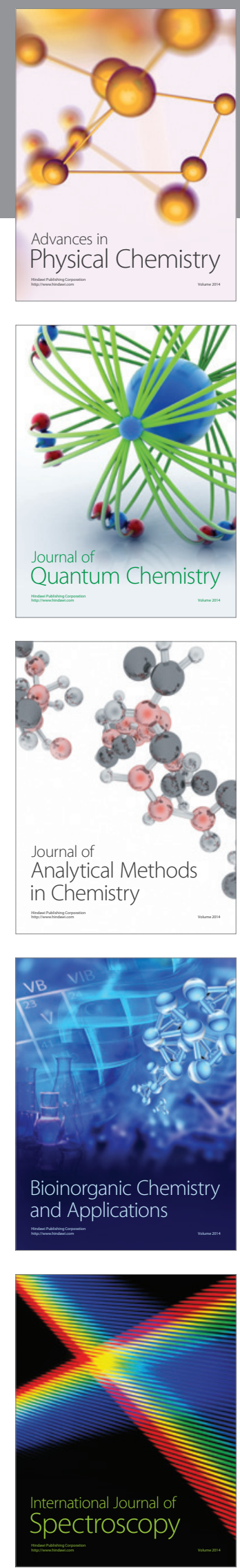